\title{
The Operation of Translation Norms in the English Version of The Great Ming Code*
}

\author{
Han Xiao \\ Guangdong Polytechnic College, Zhaoqing, China \\ Lei Li \\ Guangdong Polytechnic College, Zhaoqing, China
}

\begin{abstract}
The Great Ming Code is one of the most influential codes in Chinese history, and its English version by Jiang Yonglin is undoubtedly counted as a new milestone in the study concerning with translation of Chinese legal classics. This research, based on the English translation of The Great Ming Code, is intended to show that the various norms in the source and target culture have a significant role to play during the translation process due to the fact that readers' reception is the priority for translators. It is also found that such translation catering for the target readers without leaving the exotic culture out is very likely to be accepted and even welcomed by the target reader for the translation fits the readers' expectation in the target society.
\end{abstract}

Index Terms-The Great Ming Code, translation norms, expectancy norm

\section{INTRODUCTION}

The Great Ming Code, also called The Great Ming Code with Commentaries Attached by Regulations, has a far-reaching significance in Chinese legal history. It was enacted in the war period and finally completed in the Hongwu Period when law and regulations were attached great importance. The Hongwu reign was, to a large extent extent, regarded as one of the most important time in Chinese legislative history, during which period plenty of Chinese influential regulations and codes were enacted and then further promulgated. However, none of these regulations have been attached greater importance than The Great Ming Code and it was accordingly functioned as the basic law of the Ming dynasty in China. Zhu Yuanzhang looked at The Great Ming Code as a holy institution. The law compilers put forward that The Great Ming Code was the rule for ongoing generations. The judicial officials counted it as the enduring code of ten thousand generations. The Great Ming Code, as the law of the whole Ming dynasty, supplied basic principles and rich remedies about approaches to solving the legal problems of the land and provided significantly judicial regulations for activities during the year of the Hongwu reign. Thus, it is well acknowledged that The Great Ming Code, the basic law of the Ming dynasty, is embodied through its holistic feature and its place in the comprehensive legal system of the Hongwu reign in ancient China. Inheriting the historic merits of ancient Chinese legal codes of previous dynasties before Ming dynasty, The Great Ming Code gave a comprehensive summary of ancient Chinese laws by regulating social relations with dividing crimes into six broad categories according to the six major branches of the central government: personnel, revenue, rites, wars, justice, and public works, which signified a great change in Chinese legislative history. In addition, the code lays a solid foundation for the legislation of Qing dynasty and provides valuable references for the legal construction of modern China. As an important code of Chinese feudal society, The Great Ming Code embodies its own feature, such as the briefer regulations than Tang Code and more strict spirit than Song Code and so on, showing its development and creation in form and content. The translation, known as The Great Ming Code (Da Ming Lï), was completed by Jiang Yonglin in 2005. It was the first time The Great Ming Code had been translated into a European language. The translation played a significant role for western scholars and legal researchers to gain insights into the Chinese legal system in Ming dynasty. Due to the increasing interaction between culture, society and law, understanding of Chinese legal foundation was undoubtedly a great urgency for western countries to promote trading access into China. Even if The Great Ming Code is in form exclusively a criminal code, its translated version is also able to provide certain crucial information about ancient Chinese society, culture, and law and so on.

It has often been claimed that translational norms are common at a given time and within a certain society, which, more often than not, governs the selection, production and even the reception of translation acts (Schäffner, 1999). Admittedly, norms are indispensable elements of the every act of translating process. In the long history of studies on Chinese classics translation, much thought has been devoted to the contrastive study different translations under various

\footnotetext{
* This project is funded by Department of Education of Guangdong Province through grant number 2017WQNCX167 ( The English Translation of The Great Ming Code and Dural Roles of The Translator's Discursive Construction ) and Guangdong Polytechnic College via grant number GKJ2018034 (A Study of Translation Norms and English Translation of The Great Ming Code).
} 
conditions. Nonetheless, becoming aware of the norms and their operations is undoubtedly significant in this filed to broaden the research perspective and uncover the myth or the underlying implications behind the translation. Therefore, a close investigation of the translator's plural and dynamic habituses is necessary for the study of English version of The Great Ming Code.

\section{Methodology}

Example-based and norm theory-driven qualitative methods are embodied in the research, coupled with inductive, documental and comparison in the analysis of Jiang Yonglinb's subjectivity in translation of The great Ming Code.

A certain range of examples are evidenced by those accessible strategies of domestication and foreignization when translating so as to maximize the relevance of communication for the intended readers/receptors. Meanwhile, Jiang Yonglin's expectancy norms and professional norms are especially illustrated and probed into so as to reveal the translator's translation objectivity and further foster the understanding of the translated text.

\section{RESULTS AND ANALYSIS}

\section{Translation Norms}

Norm is initially a social concept applied in the the filed of translation studies by Jiri Levy (1969 [1963]) and James S Holmes (1988). Norms are essential and central to the every act of translating process. Norms are said to be a category for descriptive analysis of translation phenomena (Toury, 1988), that is to say, norms are the translation of general values or ideas shared by a certain community as to what is right and wrong, adequate and inadequate in to specific performance-instructions appropriate for and applicable to specific situations (Toury, 1980). Norms can be divided into three categories: (1) preliminary norms, which govern the translation strategy and the selective source text; (2) initial norms, which decide the translator's choice whether to cater for the source readers or the target readers and (3) operational norms, which influence the translators' actual decisions while translating (Toury,1980). Bartsch (1987) regards norms as the social reality of correctness notions. It is well acknowledged that there are some regulations that are counted as appropriate or right to guide people's behavior and expectations about the products, in particular with translational process. The scope of sociability covers all our activities (Davis,1994); and translation is of course such an activity taking place in the sociocultural environment. If norms act as constraints on behaviour, foreclosing certain options while suggesting others (Hermans, 1991), then they can, to a certain extent, also supply rules and models for correct and adequate behaviour just as Chesterman has put that norms consist of the selective products, translation process and behaviors and the reception of translation (Chesterman, 1993).Specifically, translation is norm-governed and it is never immune from personal or social values, nor it is transparent. On the contrary, it recreates and transforms everything within its grasp, embodying the values shared by a community (Robinson, 1999). Accordingly, all translation strategies adopted in the translation process are thus primarily governed by such norms, and not (dominantly or exclusively) by the two language systems involved.

Based on the research by Toury and Hermans, Chesterman $(1993,1997)$ differentiates between expectancy norms and professional norms. Expectancy norms can be illustrated as what the target readers expect the translated version to be "with regard to grammaticality, acceptability, appropriateness, style, textuality, preferred conventions of form or discourse and the like" (Chesterman, 1993: 17). Expectancy norms have become based on professional norms rather than the other way around. Professional norms, more often than not, govern the accessible strategies and methods during the translation process, and thus exert huge influences on concrete translation process. Professional norms involve such three major types as accountability norms, communication norms, relation norms. Accountability norms, also called ethical norms, refers to the fact that the translator should always bear the original writer, translator himself, potential readers and relevant aspects while translating, neither rewriting the text without any relevance nor creating the new text. Communication norms require that the translator should exert every effort to render the realization of every communicative action to the fullest and thus ensure the smooth communication between both the source party and target party. Relation norms, namely language norms, show that translators, under the constraint of expectancy norms, adopt concrete strategies during the translation process adhering to accountability norms. Relation norms are concerned with the relation between the source text and target text which can't be described in terms of the traditional concept of equivalence, but the proper relations between the source text and translated text governed by the text type, the agency's request, original writer's goal and the potential readers' expectancy.

Chesterman' translation norms theory put the translation activity under the influence of such factors as language, culture and society and so on, pointing out that the translator is affected both by the constrict of source language and target language, readers' expectancy, target culture's tradition, ideology, and social economy so as to reach the felicity relation rather than the simple equivalent relation, which embodies great implications for the analysis of translator's translation strategies and translation features thus configured. As the participant of social activity, the translator is more often than not influenced by expectancy norms during the translation process, and adopts certain translation strategies to foster the realization of translation objectives promoted by the professional norms and thus presents unique translation features.

The Application of Translation Norms in the English Version of The Great Ming Code 
As a matter of fact, it is always the translator herself or himself who decides which text to choose and how to translate, be that decision fully conscious or not. Every act of translation involves a unique encounter of the translator with a text within a specific communication situation carrying norms and values. As such, it goes without saying that the translation of The Great Ming Code inevitably is concerned with certain norms governing the translation strategies and further influencing reception of the translation version.

\section{The Translation Strategies in the English Version of The Great Ming Code}

Translation may be defined as follows: the replacement of textual material in one language (SL) by equivalent material in another language (TL) (Catford, 1965), or more specifically,translation is a linguistic phenomenon, served as an operation performed on languages. As a result, translators must cope with linguistic problems caused by the distance between English and Chinese. Generally speaking, it can be said that the difficulty of a legal translation depends primarily on the affinity of the legal systems and only subsidiarily on the affinity of the source and target languages (cf. De Groot 1991; also de Groot 1987).

Example 1:

\section{Chinese version:}

應議者之父祖有犯

其餘親屬奴僕管莊佃甲倚勢虐害良民凌犯官府者加常人罪一等止坐犯人不在上請之律其餘親屬謂皇親國戚及 功臣之房族兄弟伯叔母舅母姨夫始妻兄弟兩姨夫外甥妻姪之類及家人伴當管莊佃甲倚仗威勢虐害良民凌犯官府 者事發不須奏聞比常人加罪一等科斷止坐犯人本身

English version:

Committing Crimes by the Parents or Paternal Grandparents of Those Entitled to the Eight Deliberations [Yingyizhe zhi fuzu youfan]

If other relatives, bond servants [nupu], bailiffs [guanzhuang] or chief tenant farmers [dianjia] presume upon their powerful connections to bully respectable people or offend government offices, the penalties for them shall be increased one degree over those for ordinary persons. Only punish the criminals. This is not governed by the provision of petitioning the throne. ("Other relatives" refers to relatives such as paternal male third cousins [fangzu xiongdi], father's male second cousins [fangzu boshu], maternal uncles [mujiu], maternal aunts' husbands [muyifu], paternal aunts' husbands [gufu], wife's brothers, wife's sisters' husbands, sisters' sons, and wife's nephews. If these persons or domestic bond servants, bailiffs, or chief tenant farmers use their power and influence to bully respectable people or offend government offices, when the affairs come to light, they may not be memorialized. The penalties shall be increased one degree over those for ordinary persons. Only punish the criminals themselves.)

As is evidenced by the above example, such conceptions embodying Chinese culture as 奴僕管莊佃甲 and 房族兄 弟伯叔母舅母姨夫 are translated into bond servants [nupu], bailiffs [guanzhuang] or chief tenant farmers [dianjia], paternal male third cousins [fangzu xiongdi], father's male second cousins [fangzu boshu], maternal uncles [mujiu], maternal aunts' husbands [muyifu], the combination of literal translation and a set of Roman pinyin system. It is without doubt that such method is a wise choice that the ambiguity caused by cultural differences can be to a large extent avoided, after all, it is indeed a complex system of family relationship in Chinese culture which will definitely frustrate the target readers. Needless to say, the more the translators take into consideration the source text, the more elements they are able to translate. Translators, when searching for equivalents, often tend to generalize when they can't find the specific term, drawing from options available in the target culture. Though far from acceptable, exceptions certainly exist. On the other hand, The Great Ming Code has a pivotal role to play in Chinese ancient legal system and the pinyin system can enable those who would like to get a deeper knowledge of Chinese society to peek at the distinguished legal and social features.

\section{Example 2}

Chinese version:

收留迷失子女

凡留人家迷失子女不送官司而賣為奴婢者杖一百徒三年為妻妾子孫者杖九十徒二年半若得迷失奴婢而賣者各 減良人罪一等被賣之人不坐給親完聚

\section{English version:}

Taking Stray Children [Shouliu mishi zinu]

In all cases where [persons] take stray children of other families and do not send them to the authorities but send them as slaves, they shall be punished by 100 strokes of beating with the heavy stick and penal servitude for three years. If [they sell them] as wives, concubines, sons, or sons' sons, they shall be punished by 90 strokes of beating with the heavy stick and penal servitude for two and one-half years. If they get stray slaves and sell them, the penalty shall be reduced one degree from that for [selling] honorable people. Those who are sold shall not be punished and shall be returned to their relatives for reunion.

Once carefully observed, it will be noticed that addition is common throughout the English version. The the above example of supplying supplemental information like "persons", "they sell them", "selling" in the form of brackets "[]" is rather popular with different translation in order to make it more fluent and easy to understand for target readers, otherwise it will more or less discourage those getting in touch in with Chinese legal classics for the first time from 
going on with their study, and thus it can be drawn that Jiang Yonglin is very attentive to the the translation and thus domestication is adopted to foster the accessibility of the English version.

\section{Example 3}

\section{Chinese version:}

同僚犯公罪

若申上司不覺失錯准行者各遞減下司官吏罪二等謂如縣申州州申府府申布政司之類若上司行下所屬依錯施行 者各遞減上司官吏罪三等謂如布政司行下府府行下州州行下縣之類亦各以吏典為首

\section{English versions:}

Committing Public Crimes by Those in the Same Office [Tongliao fan gongzui]

If lower officers send up reports to higher officers, and the higher officers do not discover the mistakes or errors in them and allow them to be carried out, then the officials and functionaries in the higher offices shall have their punishment successively reduced two degrees from that for the officials and functionaries in the lower offices. (This refers to cases such as those where districts send up reports to subprefectures, subprefectures send up reports to prefectures, or prefectures send up reports to Provincial Administration Commissions.) If higher officers send down documents to lower officers, the lower officers carry them out even though there are errors in them, them in each case the officials and functionaries shall have their punishment reduced three degrees from that for officials and functionaries in the higher offices. (This refers to cases such as those where Provincial Administration Commissions send down documents to subprefectures, or subrefectures send down documents to districts.) In each case the functionaries shall also be principals.

Such sentences beginning with “謂如...” are originally the essential and indispensable parts of the The Great Ming Code, nonetheless, they are rendered into English in the form of brackets “( )”, for example “謂如縣申州州申府府申 布政司之類” are translated into “(This refers to cases such as those where districts send up reports to subprefectures, subprefectures send up reports to prefectures, or prefectures send up reports to Provincial Administration Commissions.)” and “謂如布政司行下府府行下州州行下縣之類” is rendered into “(This refers to cases such as those where Provincial Administration Commissions send down documents to subprefectures, or subrefectures send down documents to districts.)". By adding the brackets "( )", Jiang Yonglin, as an interlingual intercultural mediator, is intended to convey the implication that readers can selectively read and then research the regulations, that is, if there are some explantary regulations like “謂如...”, readers can skip this part so as to reduce the potential burdensome reading task without changing substantially the original text.

\section{Example 4}

\section{Chinese version:}

凡各衙門及倉庫但有附餘錢糧須要盡實報官明白正收作數若監臨主守將增出錢糧私下銷補別項事故虧折之數 瞞官作弊者並計䁍以監守自盜論

\section{English version:}

In all cases where any yamen, granary, or treasury has excess money or grains, it must be reported completely and accurately to the government and be clearly recorded in account books in the correct amount. If the supervisors or custodians secretly use the surplus money or grain to make up the deficits in other accounts, and thus cheat the government and practice fraud, then calculate the amount as illicit goods; they shall be punished on the basis of supervisors or custodians themselves stealing.

As Rosenne warned, terminological incongruence presents the greatest threat to the uniform interpretation an application of a parallel legal text (1987). Translators do not necessarily ignore aspects of the source text, but sometimes particular terms are simply unavailable, so they make do the best they can. Accordingly, translators must take care to use terms aptly express the intended meaning of the source text at the time it was produced. As illustrated by the above example, yamen, as the system-bound term, is the justice department and the highest institution in charge of the local affairs in ancient China. It is peculiar to Chinese culture and there isn't correspondent word or concept that can accurately convey the connotation of yamen. Nor the term xiucai, signifying cultural-specific realia which is the title given to those outstanding elites passing the specific exam in ancient China, has equivalent in other countries. As for such terms with no comparable counterparts in other legal and cultural systems, Roman pinyin is adopted by Jiang Yonglin to restrain the Chinese culture and peculiarity. Normally this doesn't create a serious problem for readers, rather, it has not significantly changed the terms and the triadic notion of reference and is indeed easier to discern Chinese legal and social culture. After all, as far as terminological studies are concerned, equivalence has always remained a relevant not absolute factor (Snell-Hornby 1988; Felber 1993; Arntz 1993).

\section{Example 5}

Chinese version:

別籍異財

凡祖父每父每在而子孫別立戶籍分異財產者杖一百須祖父每父每親告乃坐若居父每喪而兄弟別立戶籍分異財 產者杖八十須親以上尊長親告乃坐

\section{English version:}

Establishing Separate Household Registers of Dividing the Family Property [Bieji yicai] 
In all cases where paternal grandparents or parents are living, and sons or sons' sons establish separate household registers or divide the family property, they shall be punished by 100 strokes of beating with the heavy stick. (They shall be punished only if the paternal grandparents or parents accuse them to the court in person.) If, during the mourning period for their parents, brothers establish separate household registers or divide the family property, they shall be punished by 80 strokes of beating with the heavy stick. (They shall be punished only if their superior or older relatives of the mourning degree of one year or closer accuse them to the court in person.)

As evidenced by such example as "If, during the mourning period for their parents, brothers establish separate household registers or divide the family property, ..." instead of "If brothers establish separate household registers or divide the family property during the mourning period for their parents,...", it is obvious that the latter sentence is more likely to be accepted by the target readers and meet and readings of English readers. Nonetheless, strict observance of the syntax and grammar of the source language is adopted by Jiang Yonglin and it is fidelity to the original which accounts, not the beauty or elegance of the target language. On the other hand, the language features of legal English are preserved like long sentences, passive voice and sentences beginning with "in all cases where" and "if", that is, target-language formulae are used in the translation of The Great Ming Code to cater for the needs of English readers, which reflects the fact that it is only natural that legal rules are most frequently formulated in conditional sentences. Legal translation is the technical translation and meanwhile it embodies the characteristics of general translation (Cao, 2008). It should be noted that the statement of law remains unchanged in the above example.

\section{Example 6}

Chinese version:

賦役不均

凡有司科徵稅糧及雜泛差役各驗籍內戶口田糧定立等第科差若放富差貧那移作弊者許被貧民赴拘該上 司......受財者計䁍以枉法從重論

條例

一布按二分巡分守官直隸巡按御史嚴督府州縣掌印正官審編均從公查照歲額差使於該年均徭人戶丁糧有 力之家止編本等差役不許分外增餘銀兩貧難下戶并逃亡之數聽其空閑不許徵銀及額外濫設聽差等項差科違者聽 撫按等官紏察問罪奏請改調若各官容情不舉反治以罪

一各布政司并值隸府州縣掌印官如遇各部泒到物從公㽎酌所屬大小豐歉坐泒豪猾規利之徒買囑吏書妄禀 編泒下屬承攬害良民者俱問發附近衛所充軍各該掌印官聽從者參究治罪

\section{English version:}

Unequally Levying Taxes and Corvee Services [Fuyi bujun]

In all cases where authorities levy grain taxes shuiliang and miscellaneous corvee services zafan chaiyi, they shall investigate the number of households and individuals and field products within the registers and establish the upper, middle, and lower degrees and levy the taxes and corvee services. If they release the rich and poor people or shift the degrees and practice fraud, the aggrieved poor people may accuse them to, from bottom to top from lower to higher authorities, their superior offices....If illicit goods are accepted, calculate the amount of the goods, and they shall be punished by the heavier penalties on the basis of subverting the law.

According to Rossel, upholding the principle of fidelity to the source text does not entail reproducing the source text word for word but rather producing a text that leads to the same results in practice (Rossel, 1991). The more the translators take into consideration the source text, the more elements they are able to transfer. As is shown from the above example, the source text places precise rules on the “賦役不均” by providing such regulations as “一布按二分巡 分守官直隸巡按御史嚴督府州縣掌印正官審編均從公查照歲額差使....... 一各布政司并值隸府州縣掌印官如遇各 部泒到物從公煁酌所屬大小豐楼坐派豪猾規利之徒......發附近衛所充軍各該掌印官聽從者參究治罪”, which can be said to be rather detail and rich. Nonetheless, the English version of The Great Ming Code is intended for legal scholars, historians, and socialist and so on, and it will more ore less be difficult to understand all of the regulations to a certain degree. Faced with such difficulty, Jiang Yonglin compromises and chooses omission skill, leaving the burdensome 382 regulations in the source text out for the sake of brevity and acceptability.

\section{Translation Norms and the English Version of The Great Ming Code}

Every original work can be viewed as a re-creation of a re-recreation or by extension, a translation of a translation (Gentzler, 1993). Since norms and translation are interwoven with each other, are there any certain translation norms in that society that exert substantial influences on Jiang Yonglin's behaviour? is Jiang Yonglin powerful and competent to change norms while translating The Great Ming Code? And above all it is to what extent and in what circumstances that Jiang Yonglin based on the personal knowledge and values available about source and target rules objectively, makes choices without overstepping the boundaries of loyalty.

(1) Expectancy Norms in the Translation of The Great Ming Code

Expectancy norms allow evaluate judgments about translations since readers have a notion of what is an "appropriate" or "acceptable" translation of the specific text variety and will approve of a translated conforms to these expectations (Chesterman, 2012). Legal translation is receiver-oriented (Sarcevic, S 1997). This is all the more surprising because legal communication can be effective only if interaction is achieved between text producers and receivers, that is, the the translated version should be completed in the spirit of the target language. Because of different 
institutions, histories, cultures and sometimes socio-economic principles, each legal system has its own characteristic which makes it hard for receivers or addresses of legal texts to reach consensus. In attempt to present a receiver-oriented approach to legal translation, Jiang Yonglin, in order to be an effective text producer, must be thoroughly familiar with readers' expectations, in particular with popular and accepted translation strategies at that time. Before Jiang Yonglin translates The Great Ming Code, such legal codes as The Qing Code and Tang Code have been rendered into English and their English are well received by target readers. From the English version of The Qing Code and Tang Code, it can be discerned that explanatory information about specific information and addition of missing information or elements are employed by translators most to enrich target readers' knowledge about Chinese laws. In an attempt to follow the trends and cater for the expectations of target readers, Jiang Yonglin provides as much as background information as possible, such as the Ming Units of Measure and Money, introduction and sound and comprehensive glossary, making it easier for those who know little about Chinese legal code to get more about Chinese legal culture and then has the inspiration to go on with the English version. From the perspective of the language of legal English, the English version of The Great Ming Code shows the features of long and complex sentences and conditional sentences, and use of terms of art, etc. It is just through such skills that the acceptability of the translation can be ensured and guaranteed.

(2) Professional Norms in the Translation of The Great Ming Code

Jiang Yong, as the former president of Ming Association, has the high sense of responsibility from the perspective of accountability norms. He is so prudent and meticulous about the words and expression that the final translation has been finalized after deep discretion even though he is competent and proficient in the usage of both English and Chinese. It is this kind of accountability that motivated Jiang Yonglin to take his initiative to make selective choices when translating The Great Ming Code. Jiang Yonglin once lived in China and therefore he has a better understanding of basic feature of Chinese language and legal system. Meanwhile, he is the professor of Bryn Mawr College, lecturing Eastern Asia culture. The complex and rich life experience and extent knowledge enable him to realize the huge difference between English and Chinese, especially when translating the seemingly competed but burdensome 382 regulations (li) that were attached to the Code during the Wanli reign, such translating skill as omitting is adopted, based on Jiang Yonglin's ethical norm and his awareness of accountability to adopt proper language expression accessible to English readers, to maintain the brevity and readability of the English version after taking the features of English and Chinese language into consideration.

The English version of The Great Ming Code came to its final form in 2005, during which time the diplomatic relation between China and America is normalized, fostering the communication between culture, law and society and so on. Nevertheless, The Tang Code and The Qing Code have been rendered into English at early time, leaving the gap for getting a full and comprehensive understanding of Chinese legal system in ancient time. Thus Jiang Yonglin takes the initiative to translate The Great Ming Code to get more people have a good knowledge of Chinese legal system in that time and promote the cultural communication among countries. In order to realize this objective, the first and foremost task that the translator has to undertake is to promote the communicative function of the The Great Ming Code and enable the target readers to understand the English version as much as possible from the perspective of the communication norms. It is commonly recognized that not all of the target readers are able to fully have a deeper understanding of the English version of The Great Ming Code due to the fact that the legal language its is more often than not obscure and hard to understand. According to Jackson, it is true that legal language needs to draw upon the whole resources of the natural language for its intelligibility, but legal language may only, to the extent that it resembles ordinary language, appear to be intelligible to the layperson (Jackson 1985). Therefore, such two elements have to be taken into account while translating The Great Ming Code, that is, brevity and readability. The main function of The Great Ming Code is to get the target readers have a comprehensive and sound look at the ancient legal system from Tang to Qing dynasty, and then brevity is a prerequisite during the transmitting process so as to impress the readers deeply. Influenced by communicative norms, Jiang Yonglin will, to a certain degree, consciously adopt domestication strategies, such as providing missing information in the source text, omitting the redundant 382 regulations and using correspondent concepts in place of the source terms, meanwhile trying to preserve the English language style and norm. It has to be admitted that the communicative norms have been embodied from the rich supplemental information and left-out redundant regulations.

Directed by the communication norms and drawing on the relation norms, domestication and foreignization are combined together by Jiang Yonglin in the translation of The Great Ming Code according to his own understanding of the translation of Chinese legal classics. On the one hand, Jiang Yonglin searches for adequate equivalents in the target language so as to convert a non-equivalent functional equivalent into a near equivalent one. On the other hand, the pinyin system of romanization of Chinese terms is used throughout the Code. As a reflection of social reality, the lexicon of a language is in constant flux. New words are created to express new objects and relations. As Hardy commented: "Words have no intrinsic significance; their meaning is that which is given to them in a given milieu at a given time”(1962: 82). As illustrated by the following example, “應議者之父祖有犯” is rendered into “Committing Crimes by the Parents or Paternal Grandparents of Those Entitled to the Eight Deliberations [Yingyizhe zhi fuzu youfan]". Jiang Yonglin exerts every possible way to make the target readers better understand the meaning and implications of “應議者之父祖有犯” by rendering into “Committing Crimes by the Parents or Paternal Grandparents of Those Entitled to the Eight Deliberations and preserve the nature and exotic feature of Chinese language by using the 
pinyin system "Yingyizhe zhi fuzu youfan".

As is evidenced from the above analysis, domestication and foreignization are employed all through the translated version by Jiang Yonglin due to the constraint of accountability norms, communication norms and relation norms after taking the translation objectives and language differences between English and Chinese into consideration and following the translation ethics. Meanwhile, translation norms have the function of restriction and guidelines, and translation strategies under such norms will surely be popular in the target language. Obviously, the English version of The Great Ming Code is proved to be the well acceptable one and highly praised by target readers.

\section{Discussions AND CONCLUSIONS}

As is seen from the above analysis, Jiang Yonglin, governed by various norms, intervenes actively in the following ways:

1) fitting target readers' expectations. Addition of missing sentence elements is common in the English translation of The Great Ming Code in order to make the translation more accessible and comprehensible and such skill is indeed appropriate and proper, where domestication is adopted to foster the realization of translation objectives.

2) promoting cultural communication and building harmonious relations. Jiang Yonglin takes advantage of his own knowledge to adopt accessible strategies of domestication and foreignization when translating so as to maximize the relevance of communication for the intended readers/receptors (Gutt, 1991). Directed by relation norms, omission is employed to reduce the ambiguity and trouble caused by the cultural difference, which is proved to be effective for the translated version's popularity among receptors.

This paper offers new reflections on the role of norms and research on norms in the field of translation of Chinese legal classics and briefly refers to the case study of The Great Ming Code to broaden the research scope in such field.

\section{REFERENCES}

[1] Arntz, R. (1993). 'Terminological Equivalence and Translation' in H. Sonneveld and K. Loening (eds.) Terminology. Applications in Interdisciplinary Communication, AmsterdAm/Philadelpha: Benjamins, 5-19.

[2] Bartsch, R. (1987). Norms of Language. London: Longman.

[3] Cao, D. (2008). Translating Law. Shanghai: Shanghai Foreign Language Education Press.

[4] Catford, J.C. (1965). A Linguistic Theory of Translation. An Essay in Applied Linguistics. London: Oxford University Press.

[5] Chesterman, A. (1993). From 'is' to 'ought': Laws, norms and strategies in translation studies. Target 5, 1-20.

[6] Chesterman, A. (1997). Memes of Translation: The Spread of Ideas in Translation Theory. Amsterdam and Philadelphia: Benjamins.

[7] Chesterman, A. (2012). Memes of Translation: The Spread of Ideas in Translation Theory. Shanghai: Shanghai Foreign Language Education Press.

[8] Davis, J. (1994). Social creativity. In C.M. Hann (ed.) When History Accelerates: Essays on Rapid Social Change, Complexity and Creativity (pp. 95-110). London and Atlantic Highlands, NJ: The Athlone Press.

[9] Felber, H. (1993). Allegemeine Terminologie und Wissenstechnik-theoretische Grundlagen, Wien: Term Net.

[10] Gentzler, E. (1993). Contemporary Translation Theories. London: Routledge.

[11] Groot, G-R de. (1987). 'Problems of Legal Translation from the point of View of a Comparative Lawyer' in Netherlands Reprots to the Twelfth International Congress of Comparative Law, The Hague: T. M. C. Asser Institute, 1-19.

[12] Groot, G-R de. (1991). ' Recht, Rechtsprache und Rechtssystem' dans Terminologie et Traduction 3:279-316.

[13] Gutt, E, A. (1991). Translation and Relevance: Cognition and Context. Oxford: Blackwell.

[14] Hardy, J. (1962). 'The Interpretation of Plurilingual Treaties by International Courts and Tribunals' in The British Year Book of International Law 1961, London: Oxford University Press, 37:72-155.

[15] Jackson, B. S. (1985). Semiotics and Legal Theory. London: Routledge.

[16] Hermans, T. (1991). Translational norms and correct translations. In K.M. van Leuven-Zwart and T. Naaijkens (eds) Translation Studies: The State of the Art (pp. 155-69). Amsterdam: Rodopi.

[17] Holmes, J.S (1988). Translated! Papers on Literary Translation and Translation Studies. Amsterdam: Rodopi.

[18] Levý, J. (1969, 1963). Die literarische Übersetzung: Theorie einer Kunstgattung (Walter Schamschula, trans.) Frankfurt am Main and Bonn: Athenäum.

[19] Rossel, V. (1991). 'Toujours les textes du Code civil suisses' dans Schweizerische Juristen-Zeitung 7, 13: 201-203.

[20] Robinson, D (1999) 'Looking Through Translation: A Response to Gideon Toury and Theo Hermans in Translation and Norms. Clevedon: Multilingual Matters Ltd, 113-128.

[21] Rosenne, S. (1987). 'Conceptualism as a Guide to Treaty Interpretation' in International Law at the Time of its Codification. Essays in Honor of Roberto Ago, vol: 1, Milan: Giufre, 417-431.

[22] Sarcevic, S. (1997). New Approach to Legal Translation. The Hague; London: Kluwer Law International.

[23] Schäffner, C. (1999). 'The Concept of Norms in Translation Studies' in Translation and Norms. Clevedon: Multilingual Matters Ltd, 1-8.

[24] Snell-Hornby, M. (1988). Translation Studies, An Integrated Approach, Amsterdam: Benjamins.

[25] Toury, G. (1980). In Search of a Theory of Translation. Tel Aviv: The Porter Institute for Poetics and Semiotics. 
Han Xiao was born in January of 1990 in Henan Province of China. She obtained her master degree in Southwest University of Political Science and Law in China in 2017. She is currently an English teacher of the Foreign Languages Department at Guang Dong Polytechnic College. Her research interests include legal translation and forensic linguistics.

Lei Li was born in October of 1990 in Henan Province of China. He obtained his master degree in Southwest University of Political Science and Law in China in 2017. He is currently a teacher of Political \& Ideological department at Guang Dong Polytechnic College. His research interests involve law and social science. 